\title{
Stwarzanie obcego - o istocie wrogości. Próba analizy filozoficznej
}

W prezentowanym artykule autor zastanawia się, czym jest wrogość jako taka, przyjmując, iż ludzie z natury są wobec siebie raczej przychylni, pozbawieni negatywnych odczuć. Nie chodzi o dokładne opisanie kategorii „obcego”, ale ważniejszy jest sam proces, który sprawia, że ktoś zostaje w ten sposób określony. Wrogość jest czymś wtórnym, pochodnym, zatem tym, co przeinacza, przekłamuje prawdę o człowieku. Nie sposób jednak powiedzieć, co tak naprawdę skłania człowieka do tego, by wyzwoliła się w nim postawa wrogości. Jak rozgrywa się ten skomplikowany, jak można mniemać, akt przejścia od traktowania kogoś jako „innego” do myślenia o nim w kategorii „obcego”? Autor próbuje wskazać kilka istotnych wątków, by dojść do konkluzji, iż proces „tworzenia obcego”, choć sam w sobie nienaturalny, stanowi nieodłączny element świata, w jakim żyjemy. Konkluzja ta ma zawsze tragiczny wymiar.

Słowa kluczowe: obcy, wrogość, inny, natura człowieka, stwarzanie obcego

\section{The Making of the Stranger - about the Essence of Hostility.}

An Attempt at a Philosophical Study

This paper contemplates the concept of hostility working on the assumption that people are by nature friendly and deprived of negative feelings. What it takes to fit the category of 'stranger' is secondary to how one becomes one in the in the eyes of other people. It is the process that matters. Hostility is a derivative and a by-product, it twists and distorts the truth about man. It is difficult to pin down what produces or provokes a hostile attitude in people. How does this complex transition from being seen as 'different' in the eyes of the beholders to being categorised as the 'stranger' play out? The author seeks to draw the reader's attention to several apparently important themes, only to conclude that the "making of the stranger", unnatural as it might seem, is inherent to our world. This conclusion is always tragic.

Keywords: stranger, hostility, different, human nature

\section{${ }^{1}$ Kontakt: mipawl@interia.pl}


1. „Ludzie nie mają przyjemności (ale wręcz przeciwnie wielki ból) w życiu gromadnym, gdzie nie ma mocy, która byłaby zdolna trzymać ich wszystkich w strachu"2. Ludzie są równi, a skoro tak, to dążą do różnych celów. Jeżeli jednak zdarzy się, że iluś z nich zapragnie tego samego, wówczas konflikt jest nieuchronny; jeden czyni wszystko, by zniszczyć drugiego. Nie dość na tym, na chęć destrukcji nakłada się przeszywająca świadomość, myśl, iż drugi jednoczy swe siły, by destruktorowi też odebrać „życie lub wolność”. stanem wojny i to nie takiej, w której dają się uwyraźnić strony sporu. To wojna „każdego człowieka przeciw każdemu człowiekowi”" i to taka, która ma charakter permanentny. Obejmuje ona nie tylko moment rzeczywistej walki, ale też wszystko, co do niej prowadzi i po niej następuje. Wszystko zostaje przepełnione strachem, niebezpieczeństwem śmierci, gwałtem. Wrogość jest więc tym słowem, które w sposób najbardziej dosadny ukazuje istotę życia człowieka.

Tomasz Hobbes, jak niewielu myślicieli w historii, wydobywa to, o czym pozostali nie potrafili albo bali się pisać. Nasze myślenie o człowieku i złożonym świecie jego najrozmaitszych odniesień do innych ludzi, przechodziło przez wiele torów, nawiązywało do rozmaitych wątków. Faktycznie, wbrew Hobbesowi, nie wolno zapomnieć, że tym, co buduje więzi międzyludzkie, może być miłość, przyjaźń, oddanie, służba. Piszą o tym po wielokroć wybitni filozofowie, zwłaszcza współcześni, jak: Gabriel Marcel, Dietrich von Hildebrandt, Max Scheler czy Emmanuel Levinas. Jednak to, o czym pisze angielski filozof, brzmi niepokojąco i na wskroś wiarygodnie. Owszem, z jednej strony jesteśmy przekonani, iż mamy do czynienia $\mathrm{z}$ intelektualnym wybrykiem, tworem sztucznym, wręcz urojonym, $\mathrm{z}$ drugiej jednak, z czymś, co trudno zbyć milczeniem, biorąc szczególnie pod uwagę czasy, w których żyjemy. Pytanie, które po wiekach postawi Emil Cioran, zabrzmi jako dopowiedzenie wypowiedzianej myśli: „Czy w ogóle jeszcze jesteśmy z jednego plemienia, z jednej rasy, z jednego rodu? Żywiąc przesąd życia tkwiliśmy w błędzie, który stawiał nas na równym poziomie ze wszystkimi... ale teraz wymknęliśmy się gatunkowi”. Tragiczne doświadczenia XX wieku, ale też najrozmaitsze przejawy rozgrywającej się na naszych oczach współczesności, świadczą wyraźnie o tym, że pomysły Hobbesa, tudzież jego spadkobierców, nie są wyłącznie fanaberią, ale brzmią zdumiewająco trafnie. Kategoria „obcości” analizowana przez filozofów czy socjologów, pokazywana przez twórców filmowych i poetów, wydobyta z całą ostrością w nauczaniu papieża Franciszka, w kontekście kryzysu emigracyjnego, stała się dzisiaj tą, która domaga się wciąż nowych dopowiedzeń, coraz bardziej subtelnej precyzacji. „Obcy” intryguje i zniechęca, budzi zainteresowanie i lęk, ro-

2 T. Hobbes, Leviathan or the Matter, Forme, \& Power of a Common-wealth Ecclesiasticall and Civill, s. 77.

3 Tamże, s. 76.

${ }^{4}$ Tamże, s. 77.

${ }^{5}$ E. Cioran, Zarys rozkładu, przeł. M. Kowalska, Wydawnictwo KR, Warszawa 2006, s. 249. 
dzi obawę i skrajną postać nienawiści. Biorąc pod uwagę powstałe już opracowania zagadnienia, warto zastanowić się, w jaki sposób rodzi się ta kategoria, przez kogo jest produkowana, w czym lęgnie się jej źródło. Ten właśnie problem tkwi u podstaw przedkładanego tekstu.

Chciałbym się zastanowić, czym jest wrogość jako taka, przyjmując, wbrew Hobbesowi, iż ludzie $z$ natury są wobec siebie raczej przychylni, pozbawieni negatywnych odczuć. Nie chodzi więc o dokładne opisanie kategorii „obcego”, ale ważniejszy jest dla nas sam proces, który sprawia, że ktoś zostaje w ten sposób określony. Wrogość jest więc czymś wtórnym, pochodnym, zatem tym, co przeinacza, przekłamuje prawdę o człowieku. Chcąc dotrzeć do tego, czym jest wrogość, zastosowana zostanie metoda opisu fenomenologicznego. Rzecz jasna wybór ten ma charakter arbitralny i z pewnością metoda ta nie jest uprzywilejowana. Należy jednak zauważyć, że analizujemy coś, co jest nie tyle gotowym do oglądu „obiektem", danym do zbadania produktem, a raczej procesem dziejącym się w człowieku, w obszarze jego odczuć, wrażeń, również przemyśleń i kalkulacji. Potrzeba zatem szczególnego rodzaju wglądu, uchwycenia rozgrywających się w kimś zależności. Wydaje się, że metoda fenomenologiczna, polegająca właśnie na tym, by poznający przyjął taką postawę poznawczą, „która pozwala ująć przedmiot badany w czystej intuicji, tzn. w poznaniu bezpośrednim"6, daje w tym względzie dodatkowe możliwości.

2. Tezę głoszącą, iż stan wrogości nie jest czymś naturalnym dla człowieka, której sprzeciwia się Tomasz Hobbes, przyjmujemy jako rodzaj aksjomatu. Dla jej uzasadnienia wystarczy jednak przytoczyć argument o charakterze zdroworozsądkowym i zauważyć, iż w przeciwnym wypadku gatunek ludzki po prostu nie mógłby przeżyć. Owszem, angielski filozof twierdzi, iż koniecznym warunkiem przetrwania człowieka było ustanowienie prawodawcy, jednak nie sposób wykazać, dlaczego właśnie on miał uratować ludzkość przed wzajemnym unicestwieniem. Jeżeli tak, to na zasadzie analogii, również kategoria, jaką jest „obcy”, ma charakter pochodny. Zostaje on dopiero utworzony, by nie rzec „wyprodukowany” właśnie poprzez wrogość, która w kimś się zadomowiła.

Przeciwieństwem kogoś, kogo określam mianem „obcego”, jest „swój”. Zauważmy, w słowie tym kryje się głęboka treść. Swój to najpierw ten, który „generuje poczucie bliskości, przywiązania"', a to rodzi poczucie bezpieczeństwa. Swój nie jest zagrożeniem, nie wywołuje reakcji obronnej, nie zmusza do aktu wycofania, odejścia czy rezygnacji. To, co określić mogę jako „swoje”, jest dla mnie, nie w sensie przeznaczenia bądź podporządkowania, ale fundamentalnej przychylności,

${ }^{6}$ J. Krokos, Metody fenomenologiczne i ich aktualność: zarys problemu, Studia Philosophiae Christianae 34/2 (1998), s. 104.

${ }^{7}$ S. Grabias, Analityczne kategorie obcości. Zob. http://www.studiasocjologiczne.pl/pliki/analityczne_2.pdf, s. 3 (dostęp: 15.04.2018). 
sprzyjania. Nie dość na tym, swojskość wywołuje wzajemność, wiąże się „nieodmiennie z poczuciem przynależności do tego i poczuciem posiadania tego"8.

„Swój” to ten, kto posiada wszystko, co go stanowi i wszystko, co do niego należy. Nie ma on tego dzięki komuś, ani poprzez coś, na przykład gest, decyzję, czy uznanie; jest tym właśnie, kim jest i jest takim dzięki sobie. Owszem w wypowiedzianym zdaniu zawarta jest w nieuchronny sposób sugestia, iż słowo „swój” jest sformułowane i ustanowione przeze mnie, podobnie zresztą jak słowo „obcy”. Jednak w tym drugim przypadku ustanowienie ma charakter zdecydowany i radykalny, podczas gdy „Swój” jest nie tyle ustanowieniem, co raczej uznaniem stanu rzeczy. W potocznym rozumieniu, co już zostało podkreślone, skłonni jesteśmy sądzić, że słowo to znaczy tyle, co przyjazny, przychylny, w tym sensie należący do mnie. Jednak chodzi bardziej o rozumienie go jako „należący do samego siebie”. Trzeba zaznaczyć, że obydwie interpretacje zdają się uzupełniać. „Swój”, będący sobą, a przez to też dla mnie, znaczy taki sam jak ja, przynależący do tej samej grupy, społeczności, związku. Ktoś jest więc tym, kim jest, jest swój i pozostaje takim, mimo mojej obecności. Należąc do tej samej grupy, będąc obok, pozostaje jako swój, ze sobą i dla siebie.

„Swój”, pozostając sobą, jest zawsze odmienny, nie taki jak ja. Tak oto wyłania się ważna dla nas kategoria „innego”. Jest ona niezbędną do tego, by ujawnił się „obcy”. Podkreślmy, „inny” balansuje gdzieś pomiędzy swoim i obcym, przy czym wydaje się, iż jest on bliższy temu pierwszemu. Nie zawiera się w nim element negatywny, nie jest kimś, kogo się przekreśla, kogo się chce odseparować czy wręcz unicestwić. Nie sposób jednak nie zauważyć, że na gruncie języka czy potocznych skojarzeń wydaje się być inaczej; „inny” to właśnie tyle co „obcy”, obydwa zdają się być bliskie znaczeniowo. Przy uważniejszym spojrzeniu, sprawa nie jest jednak tak oczywista. Nade wszystko należy zauważyć, że „inny” nie jest kimś jednoznacznie negatywnym. Można powiedzieć, że jego status zasadza się na tym, że on sam jest właśnie odmienny, różny, „ale tu pozostajemy tylko na poziomie obiektywnie stwierdzonych różnic - dostrzegamy je, rozumiemy je bądź nie".

W sformułowaniu, iż ,inny” balansuje pomiędzy kimś, kogo określam jako „swojego" i kimś, o kim zdecydowanie twierdzę, iż jest „obcy”, zawiera się istotna dla nas myśl. Ten, który jest mi jakoś bliski, mogę tę bliskość opisywać, dookreślać, okazuje się jednocześnie odrębny, absolutnie niesprowadzalny. Józef Tischner, choć w innym nieco kontekście, powie, iż „doświadczenie innego ma dwie strony: egotyczną i alteryczną"10. Można mówić o wzajemnym przybliżaniu się i oddalaniu, zwracaniu się do siebie i od siebie, łączeniu i separowaniu. „Inny” nigdy nie stanie się mną, ale też jakoś zawsze będzie dla mnie i ze mną. Stwierdzenie to domaga się dopowiedzenia. To charakterystyczne „spięcie” jest wewnętrznie zróżnicowane,

\footnotetext{
8 Tamże.

9 Tamże, s. 4.

${ }^{10} \mathrm{~J}$. Tischner, Inny, w: tenże, Inny. Eseje o spotkaniu, Wydawnictwo Znak, Kraków 2017, s. 11.
} 
posiada niejednakowe natężenie. Owszem, „ja” jestem zawsze ten sam, natomiast na symboliczną kategorię „innego" składają się wszyscy, którzy nie są mną. Jednak ich inność nie jest dla mnie jednakowa, jednych zauważam wprost, bezpośrednio, pozostali są coraz dalej, wchodząc w skład czegoś, co można nazwać grupą, społecznością, wreszcie ludzkością. „Innym” jest jednak zawsze ktoś, konkretna jednostka czy jakiś człowiek, a nie grupa jako taka. Pozostaje on, co już zauważono, zawsze sobą, ale jest ustanawiany w relacji do mnie; istnieje więc sam z siebie, ale też ja sam nadaję mu status bycia „innym”; jest zatem, z jednej strony - dla mnie, $\mathrm{z}$ drugiej jednak - w sobie i dla siebie.

Wyodrębnijmy jeszcze jedną, kluczową dla nas kwestię. Trafnie zauważy wspomniany Tischner: „Nie ma czystego doświadczenia innego jako takiego. Ono jest abstrakcją wywiedzioną z doświadczenia jego i mojej troski, jego i mojego niepokoju, jego i mojego zmęczenia i tęsknoty, nadziei i rozczarowania" ${ }^{11}$. Co to znaczy? „ Ja", a także „inny”, to kategorie wywiedzione, pochodne. W przedstawianym tutaj kontekście, brzmią one inaczej niż ujmował to chociażby A. Kępiński pisząc: „»ja« jest punktem centralnym świata przeżyć. Wokół niego grupują się poszczególne fakty psychiczne według współrzędnych czasu i przestrzeni. Od punktu »ja « układa się czas przeszły, przyszły i teraźniejszy, a także kierunki przestrzenne: przód - tył, góra - dół, strona lewa - prawa" ${ }^{12}$. Według Tischnera wyłaniają się one ze świata wspólnych doznań, przeżyć, doświadczeń; z historii i oczekiwań; z zetknięcia ze światem przedmiotów, uczuć i zachceń. Wszystko to było przyjęte, przeżyte, zrozumiane, wypowiedziane, zostało też i wciąż zostaje przefiltrowywane poprzez świadomość, zawsze indywidualną, ale też i wspólną, swoistą dla każdego i wspólną dla wszystkich. „Inny” wyłania się w mojej świadomości jako ten, który będąc w sobie jest ze mną, jest $\mathrm{z}$ tego świata, $\mathrm{z}$ tych przedmiotów, tych oczekiwań. Mamy więc niejako wspólne podłoże, środowisko, miejsce. W tym sensie „inny” jest „swoim” i nie pozostaje nic innego, jak właśnie uznać, a nie ustanowić taki stan rzeczy.

3. „Inny” to ktoś, kto składa się na tzw. świat naturalny. Tak jak są obok mnie kamień, drzewo, kot czy pies, tak też są „inni”, ci, a raczej „ten”, kto nie jest mną. Może on pozostać sobą, będąc, nawiązując znaczeniowo do Gabriela Marcela, współtwórcą świata czy moim „towarzyszem podróży” w tymże świecie ${ }^{13}$, bądź też ewoluować, stając się „bliźnim” bądź „obcym”. Właśnie owa ewolucja wydaje się czymś charakterystycznym. Zauważmy, jeden i drugi dopiero może się pojawić, znaczy to, że nie musi. Istnieje jednak, jak się wydaje, różnica w ich wyłanianiu się. Pierwszy - czyni to niejako sam z siebie, drugi - zostaje ustanowiony.

11 Tamże, s. 15-16.

12 A. Kępiński, Schizofrenia, Państwowy Zakład Wydawnictw Lekarskich, Warszawa 1974, s. 179.

${ }^{13}$ Nawiązuję tu do sformułowania, jakiego użył francuski filozof w dziele Le mystere de l'etre, pisząc o więzi, ukrytej jedności, jaka łączy mnie z innymi bytami. G. Marcel, Le Mystere de l'Ětre, Aubier 1951. 
Gilles Deleuze wprowadza ważny wątek do rozumienia istoty bliźniego. W jaki sposób z „innego” wyłania się „bliźni”? Jest coś, co określić można jako „świat spokojny i będący w spoczynku" "14. I oto w sposób niespodziewany wyłania się zeń, „unosi twarz, która patrzy poza siebie”, ${ }^{15}$, przy czym nie jest ona ani jakimś przedmiotem, ani też podmiotem. Jest czymś całkowicie odmiennym - „światem możliwym, możliwością przerażającego świata” ${ }^{16}$. Można powiedzieć, że „inny”, stając się „bliźnim”, zaczyna mi przynosić ze sobą możliwy świat, jeszcze nie-rzeczywisty, nie-istniejący, na wskroś nie-spokojny. W „bliźnim” świat jest otwarty na wszystko, co może się w nim wydarzyć, zarówno w znaczeniu pozytywnym, jak negatywnym, na radość i smutek, szczęście i klęskę. Możliwość, przy całej nielogiczności sformułowania, jest tu jak najbardziej realna, wyczerpuje się w sobie właśnie jako możliwość, otwarcie. By lepiej zrozumieć sens tego dziwnego sformułowania, warto przywołać fragment z Martina Bubera. Pisze on: „Ten stan rzeczy można odnaleźć nawet w najdrobniejszych, momentalnych, ledwie uchwytnych dla świadomości zjawiskach. W panicznym ścisku w przeciwlotniczym schronie nagle spotykają się na moment spojrzenia dwóch nieznajomych w zdumionej i oderwanej od sytuacji wzajemności. Nie będzie się już o tym pamiętać, gdy zabrzmi syrena odwołująca alarm, a jednak coś się wydarzyło w przestrzeni trwającej nie dłużej niż chwilę. Może się zdarzyć, że w przyciemnionej sali operowej pomiędzy dwoma obcymi sobie słuchaczami, którzy równie subtelnie i równie intensywnie odbierają jakąś melodię Mozarta, zawiąże się ledwie dostrzegalna żywiołowa dialogiczna więź, której próżno szukać po zapaleniu się świateł”17. „Bliźni” stał się tutaj współuczestnikiem mojego świata, kimś, kto wszedł weń z tym wszystkim, co jest w nim samym, a uczynił to nie-przymuszając, nie-oczekując, nie-obwieszczając niczego; ukazał się jako ten oto, taki właśnie. Jednak jego pojawienie się stało się chwilą, a zarazem inspiracją, możliwością, bym sam wyłonił się z siebie, pojawił się również dla-niego.

4. Przywołany pokrótce wątek bliźniego daje nam podstawę do tego, by zanalizować już wprost fenomen „obcego". Powiedzieliśmy, że jest on niejako produktem, efektem mojego działania. Podkreślmy, nikt nie jest obcym sam z siebie, a dopiero staje się nim, konkretniej: ja go nim czynię, ustanawiam ${ }^{18} \mathrm{w}$ jego bycie.

${ }^{14}$ G. Deleuze, F. Guattari, What Is Philosophy? Columbia University Press, New York 1994, s. 17.

15 Tamże.

16 Tamże.

17 M. Buber, Problem człowieka, przeł. J. Doktór, Wydawnictwo Naukowe PWN, Warszawa 1993, s. 92.

${ }_{18}$ Pomijam tu kwestię, która zdaje się być osobnym zagadnieniem, czy ktoś poprzez to, kim jest, jak się zachowuje, czyni sam siebie wrogiem dla innych? Czy są sytuacje, w których ktoś staje się wrogiem niejako automatycznie, nieuchronnie, a co za tym idzie, nie tyle staje się, co po prostu jest dla mnie obcym? Problem zasługuje na wnikliwszą analizę, ale zauważmy, iż zasadnym jest rozróżnienie pomiędzy „wrogiem” i „obcym”. Ten pierwszy jest nim właśnie sam z siebie, poprzez swe czyny, postawę, drugi - zostaje stworzony poprzez moją „wrogość”. 
Trzeba zatem odnaleźć charakterystyczne wątki, będące przeciwieństwem tych, które przedstawione zostały powyżej. Wolno zatem dopuścić sugestię, iż „obcy” nie ujawnia mi już niczego, żadnej możliwości, żadnego otwarcia. Nie przynosi już ze sobą świata, a w nim swoich oczekiwań i niepokojów. Dzieje się tak dlatego, że świat przestaje być „spokojnym i będącym w spoczynku”, zostaje zakłócony, wyprowadzony z naturalnego stanu. Nie ma tu też wzajemnego „poszukiwania siebie”, czegoś, co buduje związek z bliźnim. Sytuacja ze schronu czy sali koncertowej nie może się już wydarzyć, a to dlatego, że nie jesteśmy już skierowani $k u$ sobie, ale przeciw sobie.

Problem „obcego", co już zostało zauważone, nie jest nieobecny w przemyśleniach filozofów czy socjologów. Wskażmy pokrótce na kilka ważnych wątków. „Obcym” może się stać ten, kto z natury rzeczy jest „inny”, przy czym sam, niejako automatycznie traci walor neutralności, stając się kimś, kogo postrzegam jednoznacznie negatywnie. To sprawia, że jest on zawsze kimś konkretnym, zostaje w sposób precyzyjny zlokalizowany i opisany. Ukonkretnienie sprawia, że podkreślony zostaje dystans między mną i nim, można wręcz powiedzieć, że wraz z precyzowaniem tego, kim jest „obcy”, odległość zostaje zwielokrotniona i wyakcentowana. Dzieje się tak niezależnie od tego, kogo określimy w ten sposób - czy będzie to ktoś spoza naszego kręgu kulturowego, żyjący w odrębnym świecie, gdzie obowiązują inne wartości, religia, zwyczaje, czy też ktoś, kto żyje tuż obok, a staje się „obcym” z racji wyznawanych poglądów, stylu życia. Ów jednoznacznie negatywny wymiar obcości nie jest przez wszystkich uznawany. Przywołajmy chociażby Georga Simmla, który widząc w „obcym” „potencjalnego wędrowca” ${ }^{19}$, chce ukazać go jako kogoś, kto owszem, „nie do końca pokonał wolność przychodzenia i odchodzenia” ${ }^{20}$, kto będąc w grupie, „nie przynależy do niej od samego początku i importuje jej cechy, nie wywodzące się z tejże grupy" ${ }^{21}$, to jednak zdolny jest on do tego, by oddziaływać na wskroś pozytywnie, ubogacając społeczeństwo.

Kategoria „obcego” doczekała się swoich definicji. Jedną z nich wypowiada polski socjolog Florian Znaniecki: „przedmiot ludzki doświadczany jest przez podmiot ludzki jako obcy zawsze wtedy i tylko wtedy, gdy zachodzi między nimi styczność społeczna na podłożu rozdzielnych układów wartości”22. Odnajdujemy tu sugestię, iż obcość ma charakter sytuacyjny, jest uzależniona od wpływów zewnętrznych, może wzmagać się i zanikać, w zależności od uznawanych bądź nieuznawanych przez nas wartości. Trzeba zatem brać pod uwagę zachodzące warunki; nie ma „obcego”, który jest nim sam z siebie, nie ma „obcości” jako takiej, są raczej warunki, które ją stwarzają. Zygmunt Bauman dorzuca inną, istotną uwagę. „Obcy”

${ }_{19}$ K.H. Wolff, The Sociology of Georg Simmel, The Free Press, New York 1950, s. 402.

${ }^{20}$ Tamże.

${ }^{21}$ Tamże.

${ }^{22}$ F. Znaniecki, Studium nad antagonizmem do obcych, w: tenże, Współczesne narody, Wydawnictwo Naukowe PWN, Warszawa 1990, s. 300. 
jest zestawiony z figurą „wroga”. Ten ostatni jest opozycją wobec przyjaciela, jednak jeden i drugi są umieszczeni w znanej mi perspektywie, znaczy to, że potrafię każdego z nich nazwać, scharakteryzować, dookreślić; „wrogowie są negatywnością wobec pozytywności przyjaciół”23. „Obcy” wyłamuje się z tego schematu, jest poza nim jako ciało obce, wymykające się, jest „niezaplanowanym, nieprzewidzianym Trzecim: nie jest ani przyjacielem, ani wrogiem, a wedle tego, co o nim wiemy, może się okazać zarówno jednym, jak i drugim”24. Istotą „obcego” jest właśnie to, że przychodząc burzy spokój, wyprowadza ze stanu równowagi, a czyni to w sposób nieuprawniony, wręcz uzurpatorski. Alfred Schuetz, austriacki filozof i socjolog, wskazuje na jeszcze jedną cechę charakteryzującą „obcego”. Powie on, iż termin ten wskazuje na „dorosłą jednostkę, żyjącą w naszych czasach i cywilizacji, która próbuje być trwale akceptowana albo przynajmniej tolerowana przez grupę, do której się zbliża” ${ }^{25}$. Będąc „przybyszem w pełnym znaczeniu tego słowa” ${ }^{26}$ może on z nią podzielać tylko jej teraźniejszość i przyszłość, jednak „pozostaje on wykluczony z przeszłych doświadczeń tejże grupy. Patrząc z perspektywy grupy, obcy jest człowiekiem bez historii”27.

5. Jak już zauważono, nie jest naszym celem szczegółowa analiza fenomenu „obcości”. Skupmy się na samym procesie tworzenia tejże figury. Tym, co sprawia, że „obcy” wyłania się w horyzoncie doświadczanego świata, jest „wrogość”. Postawmy pytanie, które zabrzmiało już na pierwszych stronach tekstu: w jaki sposób się uruchamia, kształtuje, wreszcie wyzwala? Trzeba ją odróżnić od agresji, która narasta powoli, rodzi się pod wpływem określonych czynników; rozwija się jako efekt okoliczności, zdarzeń, usłyszanych słów. Ma najrozmaitsze oblicza, umiejscawiając się w mowie, bądź też konkretnych zachowaniach. Tymczasem wrogość pojawia się nagle, można powiedzieć, jako ta, która jest produktem gotowym, już ukształtowanym. Nie ma jej mniejszego lub większego stopnia, słabszej czy bardziej natężonej postaci. Owszem, może się „wypowiadać” w sposób zawoalowany, dyskretny bądź wyrazisty, dosadny. Jednak rozpatrując ją u samych źródeł, zawsze jest ta sama, dobitna i pełna, mająca jednakowe natężenie.

Wrogość nie jest też nienawiścią, choć ma z nią wiele wspólnego. Ta bowiem znajduje swój wyraz w upartym pragnieniu szkody, krzywdy, jaka powinna spotkać adresata. Ten, kto nienawidzi, pragnie jednocześnie zniszczyć, unicestwić. Wrogość tymczasem zdaje się pozostawać w miejscu, w którym sama tkwi; niejako „nie rusza

${ }^{23}$ Z. Bauman, Wieloznaczność nowoczesna, nowoczesność wieloznaczna, Wydawnictwo Naukowe PWN, Warszawa 1995, s. 79.

24 Tamże.

${ }^{25}$ A. Schuetz, The Stranger: An Essay in Social Psychology, American Journal of Sociology 49/6 (1944), s. 499.

${ }^{26}$ Tamże, s. 502

27 Tamże. 
się z miejsca", pozostając w sobie, nie szuka zrealizowania. W tym właśnie tkwi jej wyjątkowość. Wrogość syci się sama sobą, czerpie siłę z samej siebie. Podczas gdy nienawiść może zostać zaspokojona, to wrogość wciąż żyje, odradza się, znajdując wciąż nowe źródła i kierując się ku coraz to nowym obiektom.

Czym zatem jest wrogość, postawmy raz jeszcze to pytanie? Najpierw należy zauważyć, że rodzi się we mnie, a nie w otaczającym mnie świecie. Znaczy to, że nie wywołuje jej przedmiot, czy wydarzenie, nie rodzi jej słowo, ani czyjaś obecność; raczej coś, co jest tym związane. Konkretniej: coś, co ja z tymi faktami związuję. Każdy użyty tu termin jest ważny i pełni swoją rolę. Mówimy o fakcie, o czymś, co faktowi towarzyszy, wreszcie o związku między nimi, ustanowionym przeze mnie. Fakt, to coś, co zachodzi w danym czasie i miejscu, bądź jak powie Ludwig Wittgenstein: „Fakt - jest istnieniem stanów rzeczy. Stan rzeczy jest połączeniem przedmiotów (obiektów)"28. Są też okoliczności, czyli to wszystko, co opisuje, umiejscawia, dookreśla. Jedne z nich są powiązane z faktem w sposób naturalny i oczywisty, inne pozostają $\mathrm{w}$ związku niekoniecznym i swobodnym. Problem powstaje $\mathrm{w}$ chwili, kiedy zwracamy uwagę na związanie okoliczności z faktem jako takim.

We wrogości dochodzi do sytuacji, w której przemawiają raczej one, a nie fakt jako taki, przy czym związek między nimi ma właśnie charakter nieoczywisty, a powiązanie charakter arbitralny. Owszem, nie znaczy to, że każdorazowo jestem jego autorem, bowiem zdarza się i tak, że jest on utworzony przez kogoś innego (drugiego człowieka, system polityczny, uwarunkowania społeczne, religię). Zawsze jednak jest on nagły, gwałtowny; wrogość, jak powiedziano wyżej, nie dojrzewa, pojawia się wprost, nawet jeśli nie jest jeszcze nazwana.

Nie sposób powiedzieć, co skłania danego człowieka do tego, by wyzwoliła się w nim postawa wrogości. Jak rozgrywa się ten skomplikowany, jak można mniemać, akt przejścia od traktowania kogoś jako „innego”, do myślenia o nim w kategorii „obcego"? Wpływ na to zdają się mieć zarówno zachodzące okoliczności, tak obiektywne, jak też subiektywne. Jest więc coś, co można nazwać nastrojem, panującą tendencją, skłonnością środowiska, grupy oraz tkwiąca w kimś podatność na tego typu reakcje. Tak, jak pierwszy element da się wymierzyć, pokazać, ugruntować, tak drugi jest znacznie bardziej skomplikowany. Pomocne będzie tu pytanie o to, gdzie w człowieku zakorzenia się wrogość? Czy jest ona uczuciem, czy może mniej lub bardziej klarownym osądem stanu rzeczy? Odpowiedź na to pytanie tylko z pozoru zdaje się być oczywista. Skłonni jesteśmy sądzić, iż wrogość jest nade wszystko uczuciem, wyzwoleniem niekontrolowanej gry emocji. Nie jest to koniecznie prawdziwe. Mamy do czynienia z mechanizmem dalece bardziej złożonym, by nie rzec subtelnym. Uczucie wydaje się być okiełznane, bowiem wrogość nie jest wyłącznie jakąś sekwencją nieprzychylnych uwag skierowanych do „obcego", bądź też niechęcią, nieprzychylnością, życzeniem nieszczęścia. Owszem,

${ }^{28}$ L. Wittgenstein, Tractatus logico-philosophicus, Teza 2. 
nie znaczy, że ich nie ma, przeciwnie są one wyraźnie określone, wręcz spotencjalizowane. Mają one swój jasny wyraz, zdają się być wyostrzone, natężone. Jednak nie żyją same w sobie, nie są spontaniczne. Przeciwnie, jest coś, co je niejako trzyma w ryzach, co nadaje im jasność i klarowność, co wytycza kierunek ich podążania. Uczucia tętnią, ale są wzięte w ryzy, przez co zyskują szczególny stan napięcia, są jasno wymierzone i określone, znają swego adresata i „wiedzą", w jaki sposób chcą go ująć. Właśnie to wydaje się ważne, że „uczucia wiedzą”, co się z nimi dzieje, jak one same się rozgrywają. Czy znaczy to, że w postawę wrogości zaangażowany jest rozum? Można raczej mówić o jakimś rodzaju rozumu zdeprawowanego, skażonego ${ }^{29}$. Nie jest to perfidia, bowiem ta skrywa się w sobie, dąży do tego, by samej siebie nie ujawnić. Tymczasem wrogość jest jasno wyartykułowana, nie wstydzi się samej siebie. Ma ona raczej charakter ostentacji, arogancji, zuchwałej pewności. To dlatego „obcy” właśnie jest obcym i nic tego „faktu” nie utajnia, nie ma żadnej próby skrycia, czy nazwania tegoż „innym słowem”.

6. Tym, co charakteryzuje już ukształtowaną wrogość, jest jej wewnętrzna oporność wobec ewentualnych wpływów otoczenia. Można powiedzieć, że jest ona totalnie nie-czuła, nie-podatna na jakiejkolwiek wpływy. Czerpie żywotność z samej siebie. Tę właśnie żywotność należy opisać.

Powróćmy do obrazu, który jakże plastycznie i subtelnie przedstawia Martin Buber, modyfikując jego wewnętrzną strukturę. Oto w schronie, w sytuacji krańcowego niebezpieczeństwa, realnej, a nie potencjalnej utraty życia, spotyka się dwoje ludzi. To, co się między nimi rozgrywa, zanurzone jest w sposób totalny i nieuchronny w panującej atmosferze, dziejących się okolicznościach. Dokonujące się spotkanie nie jest już zawarte w „ledwie uchwytnych dla świadomości zjawiskach", ale rozciąga się w czasie. Jest ktoś, jedna osoba, która ów czas rozszerza, oddzielając chwilę od chwili, i to tak, by każda z nich mogła wybrzmieć, zaznaczyć się. Nie ma tu mowy o „spotkaniu spojrzeń” i wzajemności, w której jedno szuka zrozumienia i drugiego, dając jednocześnie zrozumienie i wybawienie. W zamian, mamy do czynienia ze spojrzeniem, które unicestwia, odbiera prawo bycia, które mówi sobą: „nie powinieneś tu być, „jakim prawem jesteś”, „twoja obecność jest niepożądana”, „twoim przeznaczeniem jest strach, a nie nadzieja przeżycia”, „to miejsce jest zarezerwowane dla mnie”, "przynosisz ze sobą niebezpieczeństwo”. Kiedy rozbrzmiewa „syrena odwołująca alarm”, nic nie zostaje zapomniane. Przeciwnie, „obcy” będzie dalej obarczony winą, jego obecność w zajmowanym miejscu będzie w dalszym ciągu jego przestępstwem. Podobnie w „przyciemnionej sali operowej” próżno mówić o wspólnocie doświadczenia, subtelności i intensywności odbioru. Dźwięki są przeznaczone wyłącznie dla mnie, tylko ja potrafię je zrozumieć. Obecność „obcego” jest sprofanowaniem

29 Być może zasadnym jest tu użycie słowa: „opętanie”. 
sztuki, odebraniem jej znaczenia i powagi. Tutaj też nic się nie zakończy „po zapaleniu się świateł”, przestępstwo „obcego" będzie wciąż aktualne.

Zauważmy, schemat ten może powtarzać się niezależnie od zachodzących okoliczności. „Obcy” może być stwarzany niemalże w każdej sytuacji. W tym sensie wrogość jest oporna wobec otoczenia i jego wpływów, uruchamia się wedle własnej logiki. Spełnia się jednak zawsze jednorodnie, wedle ustalonego schematu, ma też swój wewnętrzny rytuał, rządzący nią porządek. Dlatego też jest w niej wewnętrzna siła, moc tworzenia świata. To kolejny charakterystyczny rys interesującego nas fenomenu. Wrogość tworzy swój świat, a co za tym idzie, ustanawia „obcego” wedle swojej miary. Twórczość ma tu charakter nieograniczony, i to dlatego „obcy” może zostać stworzony w każdym momencie i przybrać dowolną formę. Jednak ta nieograniczoność twórczości zawarta we wrogości nieuchronnie niesie ze sobą ofiary. Wrogość jest zawsze związana z czyjąś krzywdą, nieszczęściem. W tym sensie jest ona nie-sprawiedliwa, zawsze krzywdząca. „Obcy” nie jest winny, nie jest nim sam $z$ siebie, lecz został w swoim bycie ustanowiony przeze mnie. Jest on zawsze ofiarą, przy czym ja, który go utworzyłem, nigdy nie uznaję zaistniałego stanu rzeczy. Znamienne jest to, iż we wrogości „ofiara” zostaje ustanowiona tak świadomie, jak i bezwiednie. Z jednej strony dokładnie wiem, w kogo wymierzona jest moja wrogość, a z drugiej, każdy może się nią stać. Adresat nigdy nie jest anonimowy, jest zawsze nazwany i dokładnie scharakteryzowany. Wrogość ma więc zawsze charakter konkretny, a swoją konkretnością niweczy podmiotowość, unicestwia ją, odbiera prawo do istnienia. Dlatego też zawsze pozostawia po sobie, jest dotkliwie okrutna, bezkompromisowa. Dlatego „obcy” dla tego, kto go takim ustanawia, nigdy nie stanie się ani „innym”, ani też „bliźnim”. W tym sensie wrogość, choć brzmi to kontrowersyjnie, wyklucza nawrócenie.

I ostatnia uwaga. Wrogości nie da się dookreślić, zamknąć w pojęciu. Zdaje się ona tętnić, żywić sama sobą, odnajdując w sobie własne uzasadnienie. W tym też sensie jest, na swój sposób, niemożliwa do wytłumaczenia czy zdefiniowania, chociaż ten, kto stwarza „obcego”, potrafi zazwyczaj przywołać cały zestaw usprawiedliwień dla swojej podstawy. Problem polega na tym, że mają one zamocowanie wyłącznie w tym, kto je podaje. Są zatem niemożliwe do obalenia, bowiem brak im obiektywnego zamocowania.

7. Powróćmy do myśli Tomasza Hobbesa. Spojrzenie na historię świata i człowieka dostarcza niezliczonej ilości argumentów za jej słusznością. Teraźniejszość to swoista nadprodukcja „obcych”. Obcość jest czymś, co definiuje rzeczywistość, a wrogość tym, co tkwi u podstaw antropologii, a więc wizji człowieka. Tej pesymistycznie brzmiącej przesłanki, nawiązując wprost do twórczości Emila Ciorana, nie niweluje całkiem spora liczba przykładów zachowań o charakterze altruistycznym. Zasadnicza przesłanka, która stoi u podstaw przedstawionych tutaj analiz, brzmi następująco: wrogość jest zawsze produktem wtórnym. Skoro tak, to również 
„obcy” jawi się jako twór sztuczny, nienaturalny. Skąd zatem bierze się coś, co $\mathrm{w}$ swej istocie jest nienaturalne?

Przywołajmy obraz biblijny. Oto człowiek w Ogrodzie Eden. Jego naturalnym stanem jest więź z Bogiem, tym, który ustanowił tegoż człowieka w jego istocie. Stan ten da się opisać jako bezwzględną harmonię, doskonałe złożenie elementów, perfekcyjne dostosowanie. Nie dość na tym. Na tę płaszczyznę, nazwijmy ją „rozumową”, nakłada się inna. Jest nią niczym nieograniczona, najczystsza w swej postaci miłość, bezgraniczne oddanie i poświęcenie. Stwórca jak i stworzony, są „inni”, a jednak odniesieni do siebie, w pewnym sensie od siebie zależni. Nie ma bowiem więzi, jeżeli któraś ze stron nie potrzebuje drugiej, jeżeli jedna z nich jest dla drugiej zbędna, nie-potrzebna. Nieodgadnionym pozostanie pytanie: jak możliwe było to, że dla jednej ze stron, druga, w pewnym momencie stała się kimś „obcym”? Co wprawiło w ruch cały mechanizm tworzenia czegoś, co dotąd było nieznane, a jednocześnie degradujące partnera? Inaczej: co dzieje się z człowiekiem, że ten, będąc w sytuacji zagrożenia, sam staje się zagrożeniem dla drugiego, by nawiązać raz jeszcze do obrazu, którego autorem jest Martin Buber? Stawiamy pytanie o sam ruch, który uruchamia wrogość, produkującą „obcych”. Jest ono wciąż ważne i aktualne. Chociaż formułowane inaczej, wciąż brzmi jednakowo; podobnie jak niezrozumiałym jest to, jak było możliwe, by Adam w Raju, słyszący doskonałość dźwięku harmonii i miłości, nagle zaczął słuchać kakofonii i fałszu, tak też zdumiewającym jest fakt, że drugi człowiek, wyznający inną wiarę, żyjący wraz ze mną na jednej ziemi, szukający pomocy, zagrożony, nagle stał się potencjalnym zagrożeniem, wrogiem, zamachowcem. Mechanizm jest podobnie nieodgadniony.

Możliwości są dwie, i jak można sądzić, tylko dwie. Wedle jednej natura człowieka sama w sobie jest niedoskonała, wedle drugiej, cała historia, a więc wszystko, co na nią się składa podporządkowane są jakiemuś wyższemu układowi, który te niższe tłumaczy i wyjaśnia. Koniec końców, pytanie dotyka problemu zła w świecie, które jest albo wybrykiem albo elementem większej całości. Jeżeli Hobbes opowiada się za pierwszą z nich, to dokonuje tylko takiego, a nie innego wyboru, niczego przy tym, tak naprawdę, nie tłumacząc. Zasadniczy problem polega zaś na tym, że „obcy” zostaje ustanowiony, a w akcie wrogości ustanowienie to, zdaje się, według twórcy, w pełni usprawiedliwione. Zatem nawet, jeżeli czyn ten wpisuje się w jakiś wyższy porządek, to jest on nie tyle usprawiedliwiony, co raczej świadczy o niedoskonałości tegoż. I na tym polega największy, jak można sądzić, kłopot czasu, w jakim żyjemy.

Inspiracją do napisania artykułu był referat autora wygłoszony podczas Seminarium Śląskiego: „Sami swoi? Wielokulturowość we współczesnej Europie” (25-27.10.2017) 